УДК 37.015.31:17.022.1]:3.81(477)

DOI:

Олександр Купець, аспірант

Дрогобицького державного педагогічного університету імені Івана Франка

\title{
ЗАВДАННЯ МОРАЛЬНОГО ВИХОВАННЯ ЗАСУДЖЕНИХ У СИСТЕМІ ВИПРАВНИХ ЗАКЛАДІВ УКРАЇНИ
}

У статті наголошується на важливості системної, иілеспрямованої виховної роботи пенітенціарних закладів у виправленні та ресочіалізації засуджених. Стверджується, щуо ї̈ основою є моральне виховання, мета якого - спонукання засуджених до розвитку в них системи ставлень до навколишньої дійсності й самих себе відповідно до принципів та норм загальнолюдської моралі. Наголомено на визначальному впливі на формування моральності засуджених релігійного виховання. Виокремлено головні завдання морального виховання засуджених у вітчизняній пенітенціарній системі: подолання їхніх аморальних поглядів і переконань, негативних навичок та звичок поведінки; зміцнення наявних позитивних і формування нових моральних якостей; вироблення у них соціально спрямованих особистісних якостей, характеру та здібностей; формування негативного ставлення до свого злочинного минулого; активізачія сфери пережсивань вини, спокути вини; формування усвідомлених орієнтирів бачення власного майбутнього. Обтрунтовано взаємозв'язок та взаємозалежність визначених завдань у реалізації загальної пенітенціарної ідеї.

Ключові слова: виправні заклади; пенітенціарна система; виховна робота; моральне виховання; релігійне виховання; моральний потенціал; моральні якості; циіності; засуджені.

Лim. 11.

Oleksandr Kupetz, Postgraduate Student of Drohobych Ivan Franko State Pedagogical University

\section{TASKS OF MORAL EDUCATION OF CONVICTED IN THE SYSTEM OF CORRECTIONAL INSTITUTIONS OF UKRAINE}

The article emphasizes the importance of systematic, purposeful educational work of penitentiary institutions in the correction and resocialization of convicts. It is argued that it is based on moral education, which involves purposeful organized interaction of teachers and convicts in limited living conditions and activities, which aims to encourage convicts to develop a system of attitudes to reality and themselves in accordance with the principles and norms of universal morality. An emphasis is placed on the regulatory function of morality in the system of social relations, its importance in shaping the worldview of the individual and attitude to society. Emphasis is placed on the decisive influence on the formation of morality of convicts of religious education, which allows convicts to master the basics of Christian morality, to understand its basic principles, to form the need to be guided in their lives by its basic ideas and values (mercy, compassion, decency, respect, respect to serve others, etc.). The main tasks of moral education of convicts in the domestic penitentiary system are highlighted: overcoming their immoral views and beliefs, negative skills and habits of behavior; strengthening of existing positive and formation of new moral qualities; development of socially oriented personal qualities, character and abilities in them; formation of a negative attitude to one's criminal past; activation of the sphere of experiences of guilt, redemption of guilt; formation of conscious landmarks of vision of one's own future. The interrelation and interdependence of the defined tasks in realization of the general penitentiary idea are proved. Emphasis is placed on the need to combine in the moral education of convicts demanding with a humane attitude, reliance on their positive personal qualities and taking into account individual characteristics.

Keywords: correctional institutions; penitentiary system; educational work; moral education; religious education; moral potential; moral qualities; values; convicts.

A ктуальність проблеми. На сучасному етапі розвитку України як суверенної незалежної держави пріоритетним завданням залишається зміцнення й удосконалення ії демократично-правових засад, правопорядок, що передбачає гарантування належного громадського порядку, а також прав та свобод усіх її мешканців. 3 огляду на це фахівці наголошують на необхідності посилення не тільки правоохоронної функції держави, забезпечення у ній верховенства права, а й запобігання повторним правопорушенням особами, які відбувають покарання у виправних закладах. А це, зі свого боку, передбачає поліпшення системної виховної роботи 3 ув'язненими, основою якої є моральне виховання. Адже почуття власної людської гідності, самоцінності, розуміння переваг моральних цінностей та визнання їх основою соціально прийнятних норм поведінки, якими надалі будуть керуватися у своїй життєдіяльності сьогоднішні 


\section{ЗАВДАННЯ МОРАЛЬНОГО ВИХОВАННЯ ЗАСУДЖЕНИХ У СИСТЕМІ ВИПРАВНИХ ЗАКЛАДІВ УКРАЇНИ}

засуджені, можна вважати результатом морального виховання.

Аналіз останніх досліджень і публікацій. Необхідно зауважити, що проблема виховної роботи із засудженими була об'єктом наукових студій багатьох вітчизняних дослідників, зокрема Л. Багрій-Шахматова, І. Богатирьова, В. Бадири, С. Вєтошкіна [3], В. Дрижака, О. Карамана [7], О. Лисодєд [6], С. Лучко [8], А. Степанюк [6], Г. Цибульської [11], І. Яковець [6] та ін. Кожен із них розробив власну концепцію розглядуваної дефініції. Наведемо кілька визначень виховної роботи із засудженими, котрими послуговуються перелічені науковці.

Так, С. Вєтошкін під виховною роботою із засудженими розуміє “...спільну діяльність адміністрації пенітенціарного закладу, освітніх і культурних товариств та самодіяльних організацій засуджених, метою якої є здійснення виховного впливу на засуджених щодо підвищення їхнього освітнього ікультурного рівнів" [3,72]. Дослідник також виокремив і складові виховної роботи із засудженими: моральне виховання, правове виховання, трудове виховання, фізичне виховання та ін.

На думку Г. Цибульської, виховна робота 3 ув'язненими - це “система психологопедагогічних і соціально-правових заходів, спрямованих на виправлення засуджених, що має на меті підготовку їх до життя в суспільстві та послаблення негативного впливу позбавлення волі на особу і соціальну установку засудженого" [11, 8]. Дослідниця також рекомендує реалізувати упродовж виховного процесу в пенітенціарних закладах не тільки психолого-педагогічні, а й соціально-правові заходи.

Зі свого боку, дослідники А. Степанюк, І. Яковець, О. Лисодєд пропонують своє тлумачення виховної роботи із засудженими, під якою розуміють "систему педагогічно доцільних заходів, основними завданнями яких $є$ виправлення поведінки засуджених, зростання їх інтелектуального, духовного та фізичного розвитку шляхом усунення певних особистісних деформацій” $[6,41]$.

Натомість С. Лучко доводить, що виховна робота у виправних колоніях сприяє формуванню та закріпленню у засуджених позитивного ставлення до суспільно корисної роботи, потреби до сумлінного iï виконання, мотивуючи засуджених до законослухняної поведінки в колонії та за її межами. Він також стверджує, що виховна робота із засудженими постає основним чинником щодо їх виправлення й ресоціалізації та передбачає комплекс певних заходів і норм поведінки, дотримання яких є обов'язковим для осіб, позбавлених волі $[8,460]$.
Згідно 3 концепцією О. Карамана, кінцевим результатом, бажаною реальною метою виховної роботи у виправних закладах має стати створення необхідних умов для формування життєвих (людських) компетенцій засудженого, бажання та можливості діяти у конкретній життєвій ситуації відповідно до власних цінностей, ставлень та переконань, що відповідають позитивним ідеалам суспільства. Подібним чином науковцем визначена мета виховної роботи із засудженими: “Основною метою виховної роботи $є$ формування й розвиток у засуджених якостей і навичок, що стимулюють зацікавленість у виправленні, прагнення до зайняття суспільно корисною діяльністю, дотримання прийнятих у суспільстві встановлених правил поведінки" [7, 54].

Моральні аспекти як складові виховної роботи iз засудженими були предметом численних наукових розвідок. Зокрема,П. Вівчар [4], С. Дем'янчук, П. Лосик досліджували морально-правове виховання неповнолітніх засуджених у виховних колоніях; Н. Дєєва вивчала питання, які стосуються обумовленості перспектив та життєвих цілей осіб, позбавлених волі, ступенем їхньої моральної занедбаності; Г. Потанін аналізував специфіку формування моральної спрямованості особистості неповнолітнього ув'язненого.

Попри таке зацікавлення означеною проблематикою, вказані автори здебільшого розглядали іiі з позиції кримінального права, не розкриваючи власне педагогічних аспектів аналізованих питань. Саме тому вважаємо за доцільне дослідити певні чинники морального виховання у виправних закладах як основу пріоритетного впливу на засуджених. Метою нашої наукової розвідки є саме основні завдання морального виховання у виправних закладах України.

Виклад основного матеріалу дослідження. Досягнення непростих задекларованих завдань виправлення та ресоціалізації засуджених можливе тільки за умови здійснення системного, цілеспрямованого і правильно організованого впливу на них. Основним засобом та механізмом здійснення означеного впливу традиційно залишається виховна робота, що становить систему різноманітних заходів, які забезпечують досягнення цілей виправлення і ресоціалізації тих, хто перебуває у виправних закладах.

Основою виховної роботи виправного закладу $\epsilon$ моральне виховання засуджених, що передбачає цілеспрямовану організовану взаємодію педагогів та засуджених в обмежених умовах життя й діяльності, яка має на меті спонукати останніх 


\section{ЗАВДАННЯ МОРАЛЬНОГО ВИХОВАННЯ ЗАСУДЖЕНИХ У СИСТЕМІ ВИПРАВНИХ ЗАКЛАДІВ УКРАЇНИ}

до розвитку в них системи ставлень до навколишньої дійсності й самих себе відповідно до принципів та норм загальнолюдської моралі. Важливість морального чинника виховної роботи випливає $з$ того, що саме моральність виконує функцію регулювання у системі суспільних відносин. Як відомо, у моральності людини акумулюється система норм іï поведінки, що визначає іiі світогляд і ставлення до соціуму. Власне 3 огляду на те, що рівень моральної свідомості й поведінки у злочинців надто низький, вони і скоюють злочини та потрапляють до виправних закладів.

Більшість науковців суголосні в тому, що основу моральності особистості становлять знання нею норм права й моралі, наявність відповідних поглядів та переконань, якими вона керується у повсякденному житті та завдяки яким здійснює моральну саморегуляцію в суспільному оточенні. А у правопорушників моральність як компонент свідомості грунтується на системі аморальних норм, оцінок і суджень, котрі у них сформувалися під впливом багатьох негативних чинників (відсутності належного морального прикладу з боку батьків; відсутності цілеспрямованого морального виховання у відвідуваних освітніх закладах; наявності “авторитетних” друзів у кримінальних колах і тощо), які за своєю суттю суперечать загальнолюдським нормам поведінки. Звісно, керуючись у своєму повсякденному житті такими хибними поглядами й переконаннями, що мають як правило, аморальний характер, правопорушники часто неправильно вибудовують свою взаємодію із соціумом, що більше, не бачать у цьому нічого поганого.

Власне одним з основним завдань морального виховання засуджених ми вважаємо подолання їхніх аморальних поглядів і переконань, негативних навичок та звичок поведінки, зміцнення наявних позитивних і формування нових моральних якостей. Особливо важливо при цьому, на нашу думку, забезпечити стимулювання морального розвитку особистості шляхом її взаємозв' язку та взаємодії з колективом

Виховна робота із засудженими у виправних закладах, на наше глибоке переконання, має вибудовуватися на основі поєднання вимогливості 3 гуманним ставленням до правопорушників, спираючись на позитивні якості особистості, 3 урахуванням групових та індивідуальних особливостей. Ще А. Макаренко свого часу наголошував на неефективності виховання за відсутності вимогливості $[9,149]$. Виховний вплив, орієнтований лише на придушення, нейтралізацію негативних якостей особи, не дасть бажаного результату, як і вседозволеність. Із цього приводу відомий психолог С. Рубінштейн влучно зазначав, що “. ...хто хоче виправити недоліки людини, має розуміти і їі чесноти, хоча б потенційні, тобто ті властивості, які можуть бути перетворені в чесноти при належному спрямуванні моральних сил особистості" $[10,139]$.

3 огляду на все раніше сказане, виховний процес у місцях позбавлення волі визначається не стільки послідовним розвитком морального потенціалу засуджених, що супроводжується лише частковими, локальними його корекціями 3 опорою на їх домінуючий позитивний моральний досвід, скільки якісною і глибокою перебудовою більш чи менш стійкого негативного стереотипу ставлень засуджених до соціуму, закріпленого у їх аморальному досвіді. Такий процес завжди відбувається дуже складно, оскільки включає перебудову свідомості й самосвідомості особистості, руйнування іiі традиційної системи цінностей, звиклих способів поведінки, стереотипів тощо.

У цьому континенті доречно згадати трактування моралі відомим українським педагогом Г. Ващенком. Під нею він розумів “...голос совісті людини, свідомість її морального обов'язку і зв'язану з нею оцінку своїх та чужих вчинків" $[2,36]$. При цьому, як зауважує вчений, що “моральна оцінка окремої особистості може не співпадати i навіть розходитися iз загальноприйнятною. Більше того, діючи в розріз 3 моральними принципами суспільства, людина може отримувати особисту користь. Тобто навіть шахрайство може бути корисним за своїми наслідками, але совість засуджує його. Голос совісті може бути заглушений і навіть перекручений, але це не означає, що його нема. Він може навіть прокинутись, як це нерідко буває зі злочинцями, що під впливом тих чи інших причин усвідомлюють злочинність своєї поведінки" $[2,36]$.

Ми поділяємо думку Г. Ващенка про те, що “моральність людини грунтується на їі інтелектуальних, вольових і чуттєвих властивостях. Інтелект забезпечує усвідомлення своїх обов'язків, воля допомагає людині дотримуватись моральних засад, а чуттєвість забезпечує оцінку i переживання (задоволення - незадоволення) 3 приводу своїх і чужих вчинків. "Чуттєве" тут зближується 3 поняттям “сумління”, яке забезпечує людині здатність контролювати свою поведінку" [2, 63].

Проаналізувавши вже сказане, доходимо закономірного висновку, що значно більших 


\section{ЗАВДАННЯ МОРАЛЬНОГО ВИХОВАННЯ ЗАСУДЖЕНИХ У СИСТЕМІ ВИПРАВНИХ ЗАКЛАДІВ УКРАЇНИ}

результатів можна досягнути, якщо індивідуалізувати виховний вплив на засуджених, використовувати ті форми й методи морального виховання, які будуть ефективними саме для того чи того правопорушника. Для цього потрібно володіти вичерпними відомостями про кожного засудженого, добре знати про його здібності та схильності, його минуле, сімейний стан, ставлення до життя, цінності, пріоритети тощо. Наявність максимальної інформації про засуджених дає змогу вибрати і застосувати до них оптимальні заходи впливу, попередити випадки повторних правопорушень. Крім того, глибоке знання особистості правопорушника уможливлює розуміння причин здійснення ним того чи того злочину.

Отож, уважаємо, що основою виховної роботи iз засудженими щодо розвитку їх моральності мають стати індивідуальні програми виховання, які б ураховували не тільки склад і мотиви скоєння злочину, але насамперед, особистісні якості засуджених, ступінь їх соціальної занедбаності, а також передбачали поетапність системної роботи щодо їх виправлення в період відбування покарання у виправних закладах.

Поділяємо думку багатьох сучасних вітчизняних дослідників про визначальний вплив на формування моральності засуджених релігійного виховання. Адже в умовах позбавлення волі, ізольованості від суспільних процесів у людини особливо актуалізується питання сенсу життєвого шляху та його ціннісних орієнтирів. Тобто для більшості засуджених перегляд світоглядних засад і базисних релігійних уявлень стає життєво необхідним. Релігійне виховання, зі свого боку, забезпечуючи психотерапевтичний та компенсаторний впливи, дає можливість правопорушникам "розібратись у собі”, у причинах скоєння ними злочину, що більше, пом'якшити їх стресовий стан, постаючи т. зв. “моральним стимулятором розкаяння” $[2,36]$.

Не менш важливо й те, що релігійне виховання, тісно переплітаючись 3 моральним, дає змогу засудженим оволодіти основами християнської моралі, осягнути їі засадничі принципи, сформувати потребу керуватись у своїй життєдіяльності ії базовими ідеями та цінностями: милосердям, співчуттям, добропорядністю, повагою до інших, жертовністю, потребою служити іншим, безкорисливістю й доброчинністю, умінням прощати кривдників, не пам'ятаючи зла, готовністю робити добро всім ближнім тощо. Віра в Бога, страх Божий володіють колосальним потенціалом морального очищення засуджених від нагромаджених упродовж злочинної діяльності згубних звичок, аморальних поглядів та переконань. Загальногуманітарний вплив релігійного виховання на засуджених, безсумнівно, спонукає ї до кардинальних особистих позитивних змін, реалізувати які і покликані виправні заклади у співробітництві з релігійними організаціями та їх представниками.

Як відомо, сьогодні священнослужителі мають можливість відвідувати виправні заклади, відкривати у них каплички чи церкви, бібліотеки та світлиці духовної літератури. За допомогою різних форм та методів роботи із засудженими релігійні наставники сприяють їх духовноморальному вихованню, мотивують до усвідомлення ними сутності добра і зла, формують уміння розрізняти доброчинне i злочинне, соціально ціннісне й антисоціальне, виробляють потребу духовного самовиховання.

За умови, що виправлення й ресоціалізація мають відбутися під час виконання покарання, то досягти очікуваних результатів можна шляхом застосування цілого комплексу різних заходів та засобів виховної роботи. Отже, виховна робота у вітчизняних виправних закладах, спрямована на досягнення кардинальних змін особистості, передовсім має створити умови для таких змін. Увесь виховний вплив пенітенціаріїв має забезпечити формування морально-духовної життєво компетентної особистості, яка успішно самореалізується у соціумі як громадянин, сім'янин, професіонал. Власне ця мета, поєднуючи всі ланки системи виховання, постає критерієм його ефективності. Упродовж перебування правопорушників у виправних закладах усі учасники виховної роботи очікують виправлення й ресоціалізації засуджених як абстрактної довгоцільової мети, досягнення якої передбачається, однак не вимагається.

Висновки. Отже, на нашу думку, належна організація виховної роботи щодо становлення та розвитку моральності засуджених у виправних закладах є основою їх ресоціалізації. Головними завданнями морального виховання правопорушників у вітчизняній пенітенціарній системі вважаємо подолання їхніх аморальних поглядів і переконань, негативних навичок та звичок поведінки; зміцнення наявних позитивних і формування нових моральних якостей; вироблення у них соціально спрямованих особистісних якостей, характеру та здібностей; формування негативного ставлення до свого злочинного минулого; активізація сфери переживань вини, спокути вини; формування усвідомлених орієнтирів бачення власного майбутнього. Усі перелічені чинники у комплексі забезпечують реалізацію пенітенціарної ідеї. 


\section{ЛІТЕРАТУРА}

1. Адзеленко О. Перевиховати можна лише в людських умовах. URL: http://dmytroyagunov.at.ua/news/adzelenko/2012-06-01-188

2. Ващенко Г. Виховний ідеал : підручник для педагогів, виховників, молоді і батьків. Т. 1. Полтава : Полтавський вісник, 1994. 191 с.

3. Ветошкин С. Пенитенциарная педагогика в теории и практике : монография. Москва : МГСУ "Союз", 2001. 240 с.

4. Вівчар П. В. Особливості морального виховання неповнолітніх засуджених у виховнотрудових колоніях : дис. ... канд. пед. наук : 13.00.01. Тернопіль, 1999. 191 с.

5. Воспитательная работа с осужденными : сб. док. в помощь нач. отряда и воспитателю / сост.: И. Москалюк, Д. Малышев, Б. Шабельский. Киев : РИО МВД УССР, 1981. 426 с.

6. Засоби виправлення і ресоціалізації засуджених до позбавлення волі: монографія / А. Степанюк, І. Яковець, О. Лисодєд та ін. ; за заг. ред. А. Степанюка. Харків : Кроссроуд, 2011.326 с.

7. Караман О. Принципи соціально-педагогічної роботи 3 неповнолітніми засудженими в пенітенціарних закладах. Соціальна педагогіка: теорія та практика. 2011. № 1. С. 51-57.

8. Лучко С. В. Співвідношення соціальної та виховної роботи із засудженими в установах виконання покарань. Право та управління : електрон. наук. вид. / Нац. ун-т держ. податк. служби України ; голов. ред. П. Мельник. 2012. № 2. C. 459-472. URL: http://www.nbuv.gov.ua/ejournals

9. Макаренко, А. С. Сочинения : в 7 т. Москва: Изд-во Акад. пед. наук, 1958. Т. 5. 559 с.

10. Рубинштейн С. Принципы и пути развития психологии. Москва : АН СССР, 1959. 353 с.

11. Цыбульская Г. Правовое регулирование воспитательного воздействия на несовершеннолетних, осужденных к лишению свободы : автореф. дис. ... канд. юрид. наук : 12.00.08. Рязань, 2003. 20 с.

\section{REFERENCES}

1. Adzelenko, O. Perevykhovaty mozhna lyshe v liudskykh umovakh [It is possible to re-educate only in human conditions. Available at: http://dmytroyagunov.at.ua/news/adzelenko/2012-06-01-188 [in Ukrainian].

2. Vashchenko, H. (1994). Vykhovnyi ideal : pidruchnyk dlia pedahohiv, vykhovnykiv, molodi i batkiv [Educational ideal: a textbook for teachers, educators, youth and parents]. Vol. 1. Poltava. p.191 [in Ukrainian].

3.Vetoshkyn, S. (2001). Penytentsyarnaia pedahohyka $\mathrm{v}$ teoryy y praktyke : monohrafyia [Penitentiary pedagogy in theory and practice: a monograph]. Moscov, 240 p. [in Russian].

4. Vivchar, P. V. (1999). Osoblyvosti moralnoho vykhovannia nepovnolitnikh zasudzhenykh u vykhovno-trudovykh koloniiakh [Features of moral education of juvenile convicts in educational and labor colonies]. Candidate's thesis. Ternopil, 191 p. [in Ukrainian].

5. Moskalyuk, I., Malyshev, D. \& Shabelskiy, B. (1981). Vospitatelnaya rabota s osuzhdennymi [Educational work with convicts]. Sat. dock. in the assistant. detachment and educator. Kyiv, 426 p. [in Russian].

6. Stepaniuk, A. Yakovets, I. \& Lysodied, O. (2011). Zasoby vypravlennia i resotsializatsii zasudzhenykh do pozbavlennia voli: monohrafiia [Means of correction and resocialization of convicts: a monograph]. Kharkiv, 326 p. [in Ukrainian].

7. Karaman, O. (2011). Pryntsypy sotsialnopedahohichnoi roboty z nepovnolitnimy zasudzhenymy $\mathrm{v}$ penitentsiarnykh zakladakh [Principles of social and pedagogical work with juvenile convicts in penitentiary institutions]. Social pedagogy: theory and practice. No. 1. pp. 51-57. [in Ukrainian].

8. Luchko, S. (2012). Spivvidnoshennia sotsialnoi ta vykhovnoi roboty iz zasudzhenymy v ustanovakh vykonannia pokaran [Correlation of social and educational work with convicts in penitentiary institutions]. Law and management: electron. Science. issue. / Nat. Univ. tax. services of Ukraine; (Ed.). P. Melnyk. No. 2. pp. 459-472. Available at: http:// www.nbuv.gov.ua/e-journals [in Ukrainian].

9. Makarenko, A. (1958). Sochynenyia : v 7 t. [Essays: in 7 vols]. Moscov, Vol. 5, 559 p. [in Russian].

10. Rubinshteyn, S. (1959). Printsipy i puti razvitiya psikhologii [Principles and ways of development of psychology]. Moscov, 353 p. [in Russian].

11. Tsybulskaya, G. (2003). Pravovoe regulirovanie vospitatelnogo vozdeystviya na nesovershennoletnikh, osuzhdennykh $\mathrm{k}$ lisheniyu svobody [Legal regulation of educational impact on minors sentenced to imprisonment]. Extended abstract of candidate's thesis. Riazan, p. 20. [in Russian].

Стаття надійшла до редакції 30.08.2021

\section{G580801205808}

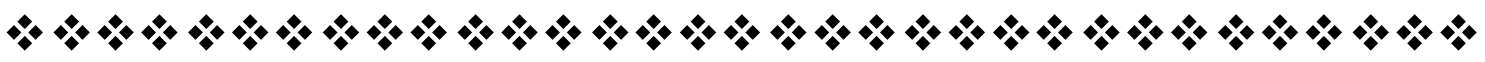

